\title{
Is protein intake saturated at doses recommended by the feeding guidelines for critically ill patients?
}

\author{
Jan Gunst ${ }^{*}$ iD and Michael P. Casaer \\ See related research by Van Zanten et al., https://ccforum.biomedcentral.com/articles/10.1186/s13054-018-2070-5
}

The ideal protein intake for critically ill patients is still debated [1]. Guidelines recommend minimum doses of 1.2$1.3 \mathrm{~g}$ protein $/ \mathrm{kg} /$ day for non-obese critically ill patients and doses up to $2.0-2.5 \mathrm{~g} / \mathrm{kg}$ ideal body weight (IBW)/day for obese critically ill patients [2]. Yet, achieved intakes often do not meet the recommended targets and several randomized controlled trials have shown absence of clinical benefit and increased ureagenesis by strategies that increased amino acid administration to critically ill patients [1]. A recent mechanistic study implicated amino acid-induced glucagon secretion as a potential mediator of amino acid catabolism, which may drive a futile cycle [3].

Recently, van Zanten et al. [4] studied the feasibility of a high-protein diet in obese critically ill patients. Patients in the intervention group received, on average, $1.49 \mathrm{~g}$ protein $/ \mathrm{kg} /$ day, compared to $0.76 \mathrm{~g} / \mathrm{kg} /$ day in the control group. As in previous studies, patients in the high-protein group had significantly higher urea levels and increased urinary nitrogen excretion [1]. In critical illness, the amount of exogenous protein net degraded into urea may be substantial. A secondary analysis of the EPaNIC study estimated that over 2 weeks, almost two-third of the supplementary amino-acids provided by 5-6 days of early-PN were net wasted in urea, thereby potentially prolonging the need of renal-replacementtherapy [5].

From the data provided by van Zanten et al., it is not possible to exactly calculate the fraction of extra-delivered proteins that were net wasted in ureagenesis. However, a rough calculation (similar to in the online supplement of [5]) suggests that, over 5 days, also about two-thirds of the extra proteins could be wasted. Indeed, estimating a median difference in protein intake

\footnotetext{
* Correspondence: jan.gunst@kuleuven.be

Clinical Division and Laboratory of Intensive Care Medicine, Department of Cellular and Molecular Medicine, KU Leuven, Herestraat 49, 3000 Leuven, Belgium
}

(C) The Author(s). 2018 Open Access This article is distributed under the terms of the Creative Commons Attribution 4.0 International License (http://creativecommons.org/licenses/by/4.0/), which permits unrestricted use, distribution, and reproduction in any medium, provided you give appropriate credit to the original author(s) and the source, provide a link to the Creative Commons license, and indicate if changes were made. The Creative Commons Public Domain Dedication waiver (http://creativecommons.org/publicdomain/zero/1.0/) applies to the data made available in this article, unless otherwise stated. accumulating up to $3.7 \mathrm{~g} / \mathrm{kg} \mathrm{IBW}$ at day 5 (based on the figure) and an (ideal) body weight of $88 \mathrm{~kg}$, approximately $325.6 \mathrm{~g}$ extra proteins were delivered to the high-protein group over 5 days, which corresponds to 52 g nitrogen. Assuming that the reported urinary nitrogen excretion corresponds to the average nitrogen excretion per day, and that the cumulative nitrogen excretion over the first 5 days corresponds to $5 \times$ that value, the supplementary urinary nitrogen loss in the high-protein group over 5 days is estimated to be $5 \times 6 \mathrm{~g}$ or $30 \mathrm{~g}$. Furthermore, assuming equal urea levels at baseline, taking into account a difference of $4.2 \mathrm{mmol} / \mathrm{l}$ blood urea nitrogen (BUN) reported at day $5(=25.2 \mathrm{mg} / \mathrm{dl}$ urea) and a urea distribution volume of $0.6 \times$ body weight, the additional nitrogen converted to BUN and not yet excreted in the urine amounts to up to $6.2 \mathrm{~g}$ at day 5. Hence, supplementary nitrogen loss over 5 days would correspond to $69.6 \%$ of the supplementary proteins provided (36.2 g extra nitrogen loss of the $52 \mathrm{~g}$ supplementary nitrogen provided).

We suggest that the authors calculate the cumulative net amount of nitrogen retained (or wasted) at several time points based on the individual patients' data. If such a calculation confirms our estimation, this would suggest that increasing protein delivery in the acute phase of critical illness up to the recommended doses for critically ill patients may be ineffective and potentially harmful. Furthermore, although hypothesis-generating, the authors may-based on their dataset-identify a time point at which catabolism becomes less resistant to feeding.

\footnotetext{
Abbreviations

BUN: Blood urea nitrogen; IBW: Ideal body weight

Funding

Both authors receive research funding from the Research

Foundation-Flanders (FWO; T003617N to JG and $1832817 \mathrm{~N}$ to MPC) and the KU Leuven (C24/17/070 to MPC and JG; STG/16/021 to MPC). JG receives a postdoctoral research fellowship supported by the Clinical Research and Education Council of the University Hospitals Leuven. The funding bodies had no role in the conception and writing of the manuscript.
} 


\section{Authors' contributions}

JG wrote the first draft. Both authors were involved in subsequent revisions.

Both authors read and approved the final manuscript.

\section{Ethics approval and consent to participate}

Not applicable.

\section{Consent for publication}

Not applicable.

\section{Competing interests}

The authors declare that they have no competing interests.

\section{Publisher's Note}

Springer Nature remains neutral with regard to jurisdictional claims in published maps and institutional affiliations.

Received: 12 July 2018 Accepted: 6 August 2018

Published online: 22 September 2018

\section{References}

1. Gunst J, Vanhorebeek I, Thiessen SE, Van den Berghe G. Amino acid supplements in critically ill patients. Pharmacol Res. 2018;130:127-31.

2. McClave SA, Taylor BE, Martindale RG, Warren MM, Johnson DR,

Braunschweig C, McCarthy MS, Davanos E, Rice TW, Cresci GA, et al.

Guidelines for the provision and assessment of nutrition support therapy in the adult critically ill patient: Society of Critical Care Medicine (SCCM) and American Society for Parenteral and Enteral Nutrition (ASPEN). J Parenter Enteral Nutr. 2016;40(2):159-211.

3. Thiessen SE, Derde S, Derese I, Dufour T, Albert Vega C, Langouche L, Goossens C, Peersman N, Vermeersch P, Vander Perre S, et al. Role of glucagon in catabolism and muscle wasting of critical illness and modulation by nutrition. Am J Respir Crit Care Med. 2017;196(9):1131-43.

4. van Zanten ARH, Petit L, De Waele J, Kieft H, de Wilde J, van Horssen P, Klebach M, Hofman Z. Very high intact-protein formula successfully provides protein intake according to nutritional recommendations in overweight critically ill patients: a double-blind randomized trial. Crit Care. 2018:22(1):156.

5. Gunst J, Vanhorebeek I, Casaer MP, Hermans G, Wouters PJ, Dubois J, Claes K, Schetz M, Van den Berghe G. Impact of early parenteral nutrition on metabolism and kidney injury. J Am Soc Nephrol. 2013;24(6):995-1005. 